\title{
Big Science, Nazified? Pascual Jordan, Adolf Meyer-Abich, and the Abortive Scientific Journal Physis
}

\author{
Ryan Dahn, University of Chicago
}

\begin{abstract}
Using newly uncovered archival sources, this essay traces the meteoric rise and fall of the peculiar interdisciplinary German scientific journal Physis, founded by the physicist Pascual Jordan and the biologist Adolf Meyer-Abich in 1941. Launched when victory for Nazi Germany seemed certain, Physis was intended by Jordan and Meyer-Abich to be a premier international journal for all sciences suitable for the new "German-led Europe" forged by conquest. Yet the journal was simultaneously a vehicle for institutionalizing Jordan's remarkably prescient vision of the future of the scientific enterprise in Hitler's state-a vision nearly identical to what is now termed "big science," yet suitably "Nazified" for wartime Germany. Behind the scenes, Physis was accompanied by a campaign of intrigue, through which Jordan and Meyer-Abich hoped to find a patron for the journal and big science among the various power centers of the Nazi state. These efforts failed, yet they nevertheless demonstrate that big science is not inherently democratic.
\end{abstract}

Tn the summer of 1942, as German troops pushed toward Stalingrad, a curious new scientific 1 journal appeared on the home front. Entitled Physis: Beiträge zur Naturwissenschaftliche Synthese (Physis: Contributions to Natural Scientific Synthesis) and spearheaded by two scientific mavericks - the theoretical physicist and cofounder of quantum mechanics Pascual Jordan (1902-1980) and the holist biologist Adolf Meyer-Abich (1893-1971) - this new organ fiercely championed a highly heterodox vision of science: one founded on the basis of biological holism (Ganzheit). Its willingness to polemicize the issue was established from page 1: the first essay,

\footnotetext{
Ryan Dahn is a Ph.D. candidate in the Committee on Conceptual and Historical Studies of Science at the University of Chicago, where he is completing a dissertation on the science and politics of the physicist Pascual Jordan. Committee on Conceptual and Historical Studies of Science, University of Chicago, 1126 East 59th Street, Chicago, Illinois 60637, USA; rwdahn@ uchicago.edu.

Acknowledgments. For their comments and criticisms on various drafts of this essay, I am grateful to Katya Motyl, Robert J. Richards, Andreas Glaeser, Lorraine Daston, Michael Rossi, Benjamin Wilson, Tara Zahra, H. Floris Cohen, and the three anonymous referees for Isis. I also thank the participants in the Transnational Approaches to Modern Europe workshop at the University of Chicago. The archival research for this essay was supported financially by grants from the Deutsche Akademischer Austauschdienst (DAAD) and the Max Planck Institute for the History of Science. An earlier version was presented at the History of Science Society Annual Meeting in November 2016.
}

Isis, volume 110, number 1. (c) 2019 by The History of Science Society.

All rights reserved. 0021-1753/2019/0110-0004\$10.00. 
written by the prime mover behind Physis - Meyer-Abich - boldly proclaimed the "collapse" of the "mechanistic ideal of knowledge" that had governed the natural sciences for a century. In place of this failed paradigm, wrote Meyer-Abich, would be Ganzheit: "Nature as such is neither an entity nor a multiplicity but, rather, a genuine, real whole." Developments since the fin de siècle in both physics and biology had augured the arrival of Ganzheit; indeed, the two fields were now beginning to merge into a greater "synthesis[,] . . . a new holistic natural science," marking a turn away from the mechanistic ideal that had led science astray. ${ }^{1}$

Although its scientific content seems anodyne to modern readers, Physis was actually a highly risky endeavor when properly viewed in the context of the late Nazi state. The journal championed several theories deemed ideologically suspect by certain factions in the Party: holism, biophysics, and quantum mechanics. Under Hitler, as prominent exponents of these theories, both Jordan and Meyer-Abich had been explicitly denounced and publicly attacked by their opponents. How, then, in the middle of a global conflict, did such a radical and polemical new scientific journal make it to print? ${ }^{2}$ To answer this question, one must delve into how, exactly, the abortive project fit into the Nazi scientific and political hierarchy.

New documents I have consulted in Meyer-Abich's Nachlass in Hamburg, opened to researchers only recently, detail how Jordan and Meyer-Abich carefully sought protection for their project among powerful entities in the bewilderingly vast hierarchy of the Nazi state. ${ }^{3}$ These documents make it clear that Physis was much more than just an everyday scientific publication and that what made it so radical was not so much its theories per se but, rather, the way it conscripted science in what Ian Kershaw has termed "working towards the Führer." just the public-facing vehicle of Jordan and Meyer-Abich's drive to institutionalize their particular conception of science as orthodoxy in the "new" Germany-or, as Jordan termed it in a letter to Meyer-Abich in September 1941, to present a "positive program of scientific renewal in the National Socialist sense." Jordan's program of "scientific renewal" was remarkably prescient for its time: he had identified a dramatic shift in the scale of the scientific enterprise, one that ultimately emerged in the United States during and after the war and was later termed "big science." As early as 1942, he envisioned an "entirely new organizational form for scientific research," massive - and costly - institutes employing armies of researchers collaboratively attacking scientific

\footnotetext{
${ }^{1}$ Adolf Meyer-Abich, "Naturwissenschaftliche Synthese," Physis: Beiträge zur Naturwissenschaftlichen Synthese, 1942, 1:5-12, on pp. 5, 6, 10. All translations throughout the essay are my own unless otherwise noted.

${ }^{2}$ Physis has received some attention from historians of science for its heterodox scientific content. See Richard H. Beyler, "From Positivism to Organicism: Pascual Jordan's Interpretations of Modern Physics in Cultural Context” (Ph.D. diss., Harvard Univ., 1994), pp. 397-479; and Kevin S. Amidon, "Adolf Meyer-Abich, Holism, and the Negotiation of Theoretical Biology," Biological Theory, 2008, 3:357-370.

${ }^{3}$ Historians have termed the power structure of the Nazi state "polycratic," for Hitler's Germany was a highly factional multipolar entity riddled with intrigue. The Physis saga presented here is an example of the ways scientists attempted to secure support and protection for their disciplines amid this complex and opaque political system. On the polycratic thesis see Peter Hüttenberger, "Nationalsozialistische Polykratie," Geschichte und Gesellschaft, 1976, 2:417-442.

${ }^{4}$ Kershaw uses this concise metaphor, a quotation from a 1934 speech by a Party functionary, to illustrate how collaboration with the regime was motivated by the desire to act in "anticipation of Hitler's presumed wishes and intentions," so as to be rewarded for successfully divining the Führer's aims. This paradigm can be applied to all forms of complicity. One could "work towards the Führer" in a direct sense, as the SS did in carrying out the Holocaust; one could also do so, as Kershaw emphasizes, in a more indirect-and often less overtly ideological-sense, in which the "objective function of the actions was nevertheless to further the potential for implementation of the goals which Hitler embodied." Jordan and Meyer-Abich were attempting via Physis to "work towards the Führer" in this second, indirect sense. See Ian Kershaw, "Working Towards the Führer': Reflections on the Nature of the Hitler Dictatorship," Contemporary European History, 1993, 2:103-118, on pp. 116, 117.

${ }^{5}$ Pascual Jordan to Adolf Meyer-Abich, 22 Sept. 1941, Staats- und Universitätsbibliothek Hamburg Carl von Ossietzky, Nachlassund Autographensammlung, Nachlass Adolf Meyer-Abich (hereafter cited as Nachlass Meyer-Abich), Ba 38, p. 1.
} 
problems on an industrial scale. ${ }^{6}$ Unlike the big science that developed after the war, though, in this vision the enterprise would be suitably Nazified so as to attract funding from Hitler's stateand Jordan and Meyer-Abich would be in charge.

The journal itself was thus the mouthpiece for a large-scale plan, and behind the scenes it was accompanied by a multipronged campaign of political intrigue. Articles were published in propaganda journals, angry denunciations were sent to Party functionaries, and feelers were extended to potential backers in the various power centers of the Nazi state. Thinking that they were smarter than their opponents, Jordan and Meyer-Abich attempted to harness the power of the Nazi regime for their own professional and personal aims. If they succeeded in finding a patron and bending the regime in their favor, their enemies would be sidelined. And with the political power of the regime at their fingertips, and their Nazi credentials suitably burnished, Jordan and Meyer-Abich would be in a position to steer the organization of big science in the "new Germany" and the "new Europe."

This essay tells the story of this attempt by Jordan and Meyer-Abich to use the regime to their advantage and institutionalize big science - an attempt that failed in almost every conceivable way. The first issue of Physis did appear, outlining Jordan's vision of Europe-wide big science under German control. But a patron for the gargantuan enterprise could not be found, despite repeated entreaties across the regime: first to the office of the Reich Student Leader, then to the Foreign Office, and finally to the Wehrmacht. Big science under Nazism never came to pass. Without a protector to vouch for their work, repeated attempts by Jordan and Meyer-Abich to get a second issue of Physis through to print were denied. Trying to outsmart the regime and use it for their own ends, Jordan and Meyer-Abich found that the Nazis remained indifferent to their efforts to "work towards the Führer" in the scientific realm. And in their search for backers of big science, Jordan and Meyer-Abich came into alliance with some of the most unsavory characters in the Nazi state. Thinking that they could use the regime, Jordan and Meyer-Abich ended up as failed collaborators.

\section{JORDAN AND MEYER-ABICH}

Born in 1902, the theoretical physicist Pascual Jordan is known as a member of the Wunderkind generation of theorists who revolutionized physics in the 1920s. When he was just twenty-four, Jordan, in collaboration with Werner Heisenberg and Max Born, coauthored the paper outlining the fundamentals of quantum theory as we know them today. Only three years later, in 1929, he was named to a professorship at the University of Rostock. On scientific merit alone, Jordan almost certainly deserved at least a share of a Nobel Prize; to his great dismay, and unlike Heisenberg and Born, he never received the award. It is at least partly for this reason that, despite scholarly attention, Jordan's is hardly a household name; even in the field of physics, he is largely forgotten. ${ }^{7}$ (See Figure 1.)

\footnotetext{
${ }^{6}$ Pascual Jordan, "Zukunftsaufgaben quantenbiologischer Forschung," Physis, 1942, 1:64-79, on p. 65. For the essay that coined the term "big science" see Alvin M. Weinberg, "Impact of Large-Scale Science on the United States," Science, 1961, 134 (3473):161-164.

${ }^{7}$ Max Born, Werner Heisenberg, and Pascual Jordan, "Zur Quantenmechanik II," Zeitschrift für Physik, 1926, 35:557-615. Sam Schweber termed Jordan the "unsung hero among the creators of quantum mechanics": Silvan S. Schweber, QED and the Men Who Made It: Dyson, Feynman, Schwinger, and Tomonaga (Princeton, N.J.: Princeton Univ. Press, 1994), p. 5. "That Jordan never won a Nobel Prize in physics is a puzzle": Don Howard, "Quantum Mechanics in Context: Pascual Jordan's 1936 Anschauliche Quantentheorie," in Research and Pedagogy: A History of Quantum Physics through Its Textbooks, ed. Massimiliano Badino and Jaume Navarro (Berlin: Edition Open Access, 2013), pp. 265-283, on p. 267. For more on Jordan's contributions to quantum theory see William A. Fedak and Jeffrey J. Prentis, "The 1925 Born and Jordan Paper 'On Quantum Mechanics,"” American Journal of Physics, 2009, 77:128-139.
} 


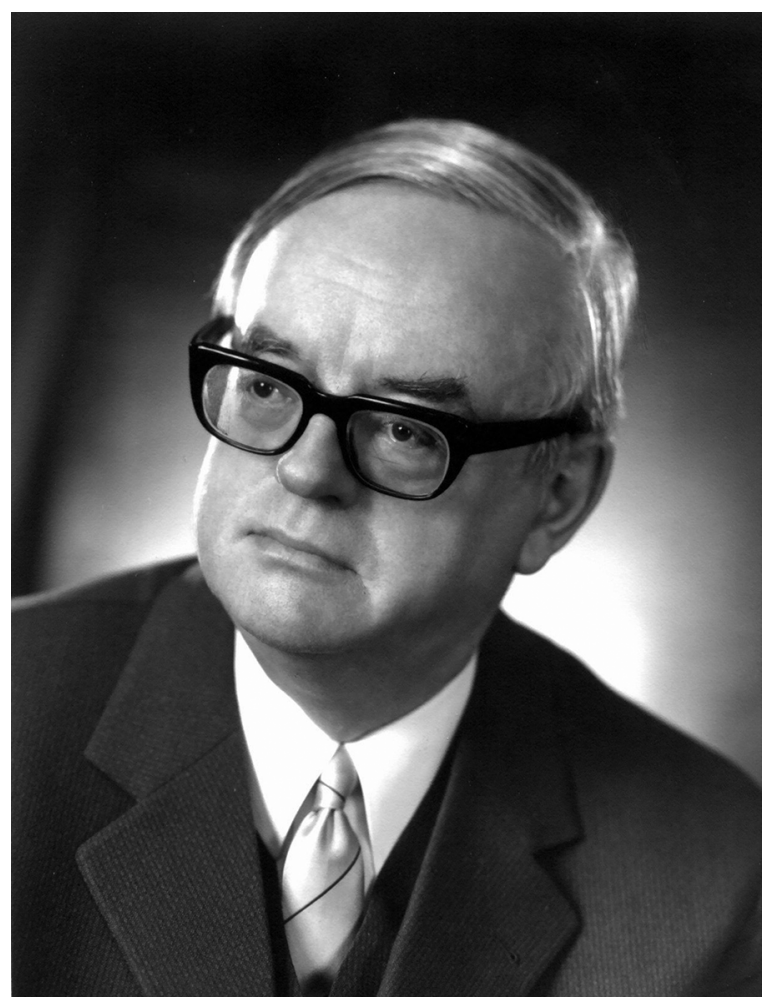

Figure 1. Pascual Jordan (1902-1980), pictured here in the 1970s. Jordan family collection.

Indeed, when Jordan is recalled today, it is not so much for his scientific contributions per se but, rather, as "perhaps the only first-tier theoretical physicist who sympathized openly and strongly with the Nazi ideology." Active in far-right circles as early as 1930, writing cultural-political articles under a pseudonym in a variety of völkisch publications, Jordan joined the Nazi Party on 1 May $1933 .{ }^{8}$ Nevertheless, he never advanced far in the Nazi polycracy, which proved fortunate for him after the war. The Physis story makes it clear, though, that this was not for lack of trying: Jordan aspired to a transformative role in scientific administration in the "new Germany," presciently recognizing that the scientific enterprise was moving toward large-scale industrial projects employing hundreds or thousands of researchers. Repeated paeans to the regime emphasiz-

\footnotetext{
${ }^{8}$ Anthony Duncan and Michel Janssen, "Pascual Jordan's Resolution of the Conundrum of the Wave-Particle Duality of Light," Studies in History and Philosophy of Modern Physics, 2008, 39:634-666, on p. 639. On the pseudonymous articles see Richard H. Beyler, "Jordan alias Domeier: Science and Cultural Politics in Late Weimar Conservatism," in Weimar Culture and Quantum Mechanics: Selected Papers by Paul Forman and Contemporary Perspectives on the Forman Thesis, ed. Cathryn Carson, Alexei Kojevnikov, and Helmuth Trischler (London: Imperial College Press, 2011), pp. 487-503. Most scholarship on Jordan has focused on his seemingly paradoxical decision to join the Party despite his many Jewish friends and colleagues. See esp. M. Norton Wise, "Pascual Jordan: Quantum Mechanics, Psychology, National Socialism," in Science, Technology, and National Socialism, ed. Monika Renneberg and Mark Walker (New York: Cambridge Univ. Press, 1994), pp. 224-254; Dieter Hoffmann, Pascual Jordan im Dritten Reich-Schlaglichter (Berlin: Max-Planck-Institut für Wissenschaftsgeschichte, 2003); and Hoffmann, "Pascual Jordan (1902-1980): Der gute Nazi," in Die Universität Rostock in den Jahren 1933-1945, ed. Gisela Boeck and Hans-Uwe Lammel (Rostock: Univ. Rostock, 2012), pp. 131-161.
} 
ing the military applications of such massive big science projects simply fell on deaf ears. Jordan's stalled career trajectory under Hitler makes plain the Party's indifference toward him. A hoped-for call from provincial Rostock to a more prestigious post came only in 1944 (to Berlin), at which point the outcome of the war was no longer in doubt. ${ }^{9}$ After denazification, Jordan resurfaced at the University of Hamburg, where he trained a generation of West German physicists and continued to engage in conservative politics. ${ }^{10}$

The biologist, philosopher, and historian of science Adolf Meyer-Abich remains comparatively little studied. ${ }^{11}$ Born in 1893 in the northern German city of Emden, Meyer-Abich studied in Göttingen and Jena, receiving his doctorate in 1916 and then serving in the German army during World War I. During the mid-1920s, Meyer-Abich worked at the Hamburg State and University Library while pursuing further studies, ultimately receiving his Habilitation in Hamburg in 1926 with a thesis on theoretical biology. ${ }^{12}$ Inspired by Alexander von Humboldt's travels, Meyer-Abich spent considerable time in Latin America both before and after the war; he was based in Hamburg after 1945, and his interests increasingly turned toward history of science as he remained on the German academic periphery. ${ }^{13}$ (See Figure 2.)

Throughout his career, Meyer-Abich fervently and consistently campaigned for a turn toward analyzing organisms as a whole; indeed, he was the leading proponent of biological holism in mid-twentieth-century Germany. ${ }^{14}$ Yet Meyer-Abich's commitment to Ganzheit extended far beyond his own field of biology. For him, holism was a unifying philosophy applicable to all scientific disciplines, one that offered a solution to what he perceived as the great failure of mechanism: its splintering of science into innumerable disparate disciplines, fields, and subfields. A holistic science, pursued in all fields, would build toward an understanding of nature in its en-

\footnotetext{
${ }^{9}$ For appeals emphasizing the military applications of big science see, e.g., Pascual Jordan, "Die Wandlung der Universität," Rostocker Universitätszeitung, 9 May 1933, pp. 3-5; Jordan, Physikalisches Denken in der neuen Zeit (Hamburg: Hanseatische Verlagsanstalt, 1935); and Jordan, "Nationalsozialistische Wissenschaft-Aufgabe ohne Kompromiß!" Wille zum Reich: Halbmonatsschrift für Politik und Kultur, 1938, 13:54-55. Jordan's own contribution to the war effort was minor; enlisting in the Wehrmacht in 1939, he served first in the Luftwaffe's weather service and then worked briefly at the V-2 rocket base in Peenemünde in 1943. After a transfer to the Navy that same year, Jordan worked in a research laboratory in Berlin before being evacuated to Göttingen in early 1945.

${ }^{10}$ On Jordan's postwar academic and political career see, respectively, Jürgen Ehlers and Engelbert Schücking, "Aber Jordan war das Erste," Physik Journal, 2002, 1(11):71-74; and Arne Schirrmacher, "Physik und Politik in der frühen Bundesrepublik Deutschland: Max Born, Werner Heisenberg und Pascual Jordan als politische Grenzgänger," Berichte zur Wissenschaftsgeschichte, 2007, 30:13-31.

${ }^{11}$ An important bibliographical note about Meyer-Abich: he was known by and published under his birth name, Adolf Meyer, until 1938; after this, he added the suffix “-Abich," his maternal family's name. Here I use Meyer-Abich for simplicity, but library catalogues still list his works under both names.

12 On Meyer-Abich's scientific career see Amidon, "Adolf Meyer-Abich, Holism, and the Negotiation of Theoretical Biology" (cit. n. 2); Felix Brahm, "Meyer-Abich, Adolf," in Hamburgische Biografie: Personenlexikon, ed. Franklin Kopitzsch and Dirk Brietzke (Göttingen: Wallstein, 2006), pp. 254-255; and Manfred D. Laubichler, "Mit oder ohne Darwin? Die Bedeutung der Darwinschen Selektionstheorie in der Konzeption der theoretischen Biologie in Deutschland von 1900 bis zum Zweiten Weltkrieg," in Darwinismus und/als Ideologie, ed. Uwe Hoßfeld and Rainer Brömer (Berlin: Wissenschaft und Bildung, 2001), pp. 229-262, esp. pp. 247-251. Meyer-Abich's own recollections are also worthy of note. See Adolf Meyer-Abich, "Atlantische Existenz," in Wege zur Wissenschaftsgeschichte, ed. Bernhard Sticker and Friedrich Klemm (Wiesbaden: Steiner, 1969), pp. 39-73, esp. pp. 51-63.

${ }^{13}$ Amidon, "Adolf Meyer-Abich, Holism, and the Negotiation of Theoretical Biology," p. 358; and Brahm, "Meyer-Abich, Adolf," p. 255.

${ }^{14}$ Meyer-Abich actually imported the term "holism" (as "Holismus") into German, translating two of John Scott Haldane's foundational works on holism from the English. See John Scott Haldane, Die philosophischen Grundlagen der Biologie: DonnellanVorlesungen, im Jahre 1930 an der Universität Dublin, trans. Adolf Meyer[-Abich] (Berlin: Prismen-Verlag, 1932); and Haldane, Die Philosophie eines Biologen, trans. Meyer[-Abich] (Jena: Fischer, 1936).
} 


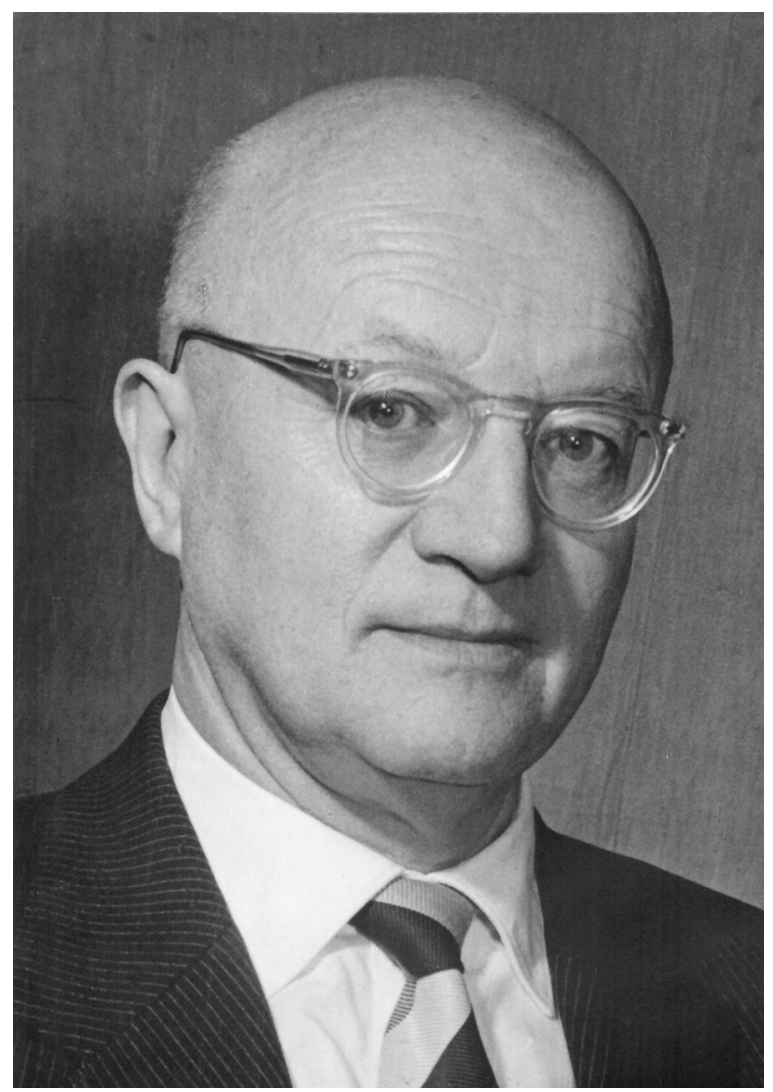

Figure 2. Adolf Meyer-Abich (1893-1971), pictured here in the 1960s. Meyer-Abich family collection.

tirety, thereby reuniting the fractured scientific enterprise. Indeed, this deep, lifelong fidelity to Ganzheit is almost certainly the reason why Meyer-Abich has largely gone unnoticed, as his is the classic story of a scientist whose work and ideas are, in the conventional telling, proven wrong and sacrificed on the altar of scientific progress. For as it turned out, the mid-twentieth century proved to be the age in which mechanism was at its most ascendant in biology; it was also an era when scientific disciplines and subfields proliferated and became ever more specialized. ${ }^{15}$ We therefore see little mention of Meyer-Abich in the literature. ${ }^{16}$ Only recently has his massive Nachlass become available to researchers, making clear what had already been apparent to those few who looked: politically, he was a staunchly conservative German nationalist. Indeed, Meyer-Abich apparently sought to join the Nazi Party after Hitler took power, but his application was turned

\footnotetext{
${ }^{15}$ Cell biology, for example, enjoyed massive midcentury success by reducing and explaining cells in terms of their constituent parts, or mechanisms. See William Bechtel, Discovering Cell Mechanisms: The Creation of Modern Cell Biology (New York: Cambridge Univ. Press, 2006).

${ }^{16}$ Meyer-Abich appears fleetingly in Anne Harrington's classic work on German holism and in Beyler's dissertation on Jordan's biological theories. See Anne Harrington, Reenchanted Science: Holism in German Culture from Wilhelm II to Hitler (Princeton, N.J.: Princeton Univ. Press, 1996), pp. 179-199; and Beyler, "From Positivism to Organicism" (cit. n. 2), pp. 82-91, 171-175, $397-479$.
} 
down, likely because he had been a member of the German Democratic Party during the Weimar years and active as a Freemason in Chile. ${ }^{17}$

\section{A FLEDGLING ALLIANCE}

The wartime collaboration began when Meyer-Abich wrote to Jordan in March 1941, extending an invitation to help him launch and coedit a new interdisciplinary scientific journal - Physisthereby sparking an intense correspondence that would last through the end of the conflict. ${ }^{18}$ Jordan quickly and enthusiastically accepted Meyer-Abich's invitation to coedit the periodical. ${ }^{19}$ From there, things moved quickly; on 24 April Jordan was sent a contract for his coeditorship from the journal's publisher, Hippokrates-Verlag. Meyer-Abich, for his part, was already soliciting articles for the new journal from his diverse network of correspondents across Europe. ${ }^{20}$ By mid-May, Jordan and Meyer-Abich were meeting to discuss Physis in person in Bremen, where Jordan was stationed with the Luftwaffe, and before the end of that month Jordan had sent MeyerAbich the manuscript for his first article in Physis. ${ }^{21}$

This promising new collaboration deepened the professional relationship between MeyerAbich and Jordan into a closer friendship. ${ }^{22}$ Crystallizing the budding alliance was a growing realization that the two were comrades of a sort. Jordan and Meyer-Abich both considered them-

\footnotetext{
${ }^{17}$ The Meyer-Abich collection comprises fifty-six boxes of material covering the 1910s through to 1970, with no obvious wartime gaps. It is thus one of the most complete collections of personal papers from a mid-twentieth-century German biologist extant today. Yet the only scholarly works that draw on this collection are Amidon, "Adolf Meyer-Abich, Holism, and the Negotiation of Theoretical Biology" (cit. n. 2); and Felix Brahm, "Das Deutsch-Dominikanische Tropenforschungsinstitut 1937-1940: Basis für eine deutsche Kolonie in der Dominikanischen Republik oder 'Experimentierfeld' für koloniale Aufgaben in Afrika?” in Der Nationalsozialismus und Lateinamerika: Institutionen-Repräsentationen-Wissenskonstrukte I, ed. Sandra Carreras (Berlin: Ibero-Amerikanisches Institut Preußischer Kulturbesitz, 2005), pp. 35-56. On the failure of Meyer-Abich's attempt to join the Nazi Party see Brahm, "Meyer-Abich, Adolf" (cit. n. 12), p. 255; and Brahm, "Das Deutsch-Dominikanische Tropenforschungsinstitut 1937-1940," p. 41.

${ }^{18}$ Aside from a single abandoned letter draft from Jordan to Meyer-Abich on the reverse side of a page of lecture notes (dated 30 Apr. 1969, Nachlass Jordan, Nr. 179, Bl. 2v, Staatsbibliothek zu Berlin), there are no extant letters to or from Meyer-Abich in Jordan's Nachlass in the Berlin State Library. This is unsurprising; the vast majority of Jordan's pre-1945 papers were apparently destroyed during the war. Thus all of the letters cited here come from the Meyer-Abich collection. Yet Meyer-Abich did not keep copies of all his outgoing correspondence, so with a single exception (one carbon copy of a letter from Meyer-Abich to Jordan, dated 22 May 1941), all surviving letters in the Meyer-Abich collection are from Jordan, meaning that only one side of the correspondence survives.

19 Jordan to Meyer-Abich, 27 Mar. 1941, 29 Mar. 1941, Nachlass Meyer-Abich, Ba 38. Jordan and Meyer-Abich likely became acquainted in the late 1930s, when Jordan turned toward biophysics; nevertheless, these are the earliest extant letters between the two.

${ }^{20}$ For the contract see Hippokrates-Verlag Marquardt \& Cie. to Jordan, 24 Apr. 1941, Nachlass Meyer-Abich, Ba 38. For MeyerAbich's solicitations see, e.g., Meyer-Abich to Kurt von Neergaard, 18 Apr. 1941, p. 2 (copy), Nachlass Meyer-Abich, Ba 58.

${ }^{21}$ The meeting probably took place on 11 May. See Jordan to Meyer-Abich, 6 May 1941, 24 May 1941, Nachlass Meyer-Abich, Ba 38. Jordan published two essays in the 1942 Physis issue; the one referenced here was almost certainly the manuscript for the first essay, an overview of Jordan's "quantum biology": Pascual Jordan, "Begriff und Umgrenzung der Quantenbiologie," Physis, $1942,1: 13-26$

22 There was a third coeditor of Physis, the anatomist Hans Petersen (1885-1946), but his role in the story was minimal. Petersen nearly resigned as coeditor before the journal got off the ground owing to serious health issues; Meyer-Abich had to beg him to stay on. He does not seem to have solicited material for Physis, meaning that his only contribution to the journal was the article he authored in the 1942 issue, an extended meditation on holism and philosophy of biology. Forgotten for years, Petersen's name has resurfaced in recent research into the gruesome trade in cadavers of Nazi victims executed at prisons in Germany during the Third Reich. See Hans Petersen to Meyer-Abich, 3 May 1941, 12 May 1941, and Meyer-Abich to Petersen, 14 May 1941: Nachlass Meyer-Abich, Ba 64; for his Physis article see Hans Petersen, "Was heißt ganzheitliche Betrachtungsweise?" Physis, 1942, 1:27-51. On Petersen and the cadaver trade see Mathias Schütz, "Das Strafgefängnis Stadelheim als zentrale Hinrichtungsstätte im Nationalsozialismus: Entwicklungen und Opfer," Zeitschrift für Geschichtswissenschaft, 2016, 64:854-875. I thank Sabine Hildebrandt for alerting me to this paper.
} 
selves proud German nationalists, and both had declared allegiance to the new regime in part by outlining how their scientific theories were compatible with National Socialism. Yet their reward for professing loyalty to Hitler had not been gratitude but, rather, a seemingly unending stream of denunciations and personal attacks from virulent elements in the Nazi Party. These attacks were all the more painful for Jordan and Meyer-Abich because they were rooted in ideological insinuations that the scientific theories they cherished were somehow "un-German" and therefore irreconcilable with National Socialism.

In Jordan's case, these enemies were the infamous proponents of deutsche Physik, the group of radical Party members who denounced and attempted to ban the teaching of relativity theory and quantum mechanics as "Jewish physics." Centered on the physicists Philipp Lenard and Johannes Stark, who had attacked Albert Einstein in the 1920s and joined the Party well before 1933, this group itself proffered scientific theories that were largely incoherent; they were united chiefly by their deep hatred of Einstein and their anti-Semitism. ${ }^{23}$ While the vast majority of German physicists accepted Einstein's relativity theory and the newly developed quantum mechanics as proven scientific fact and saw deutsche Physik as buffoonish, many were afraid of these figures' political influence; and few fought as loudly and aggressively against them as Jordan. And for the deutsche Physiker, Jordan was an obvious target: he was one of the founders of quantum mechanics and had studied with famous Jewish scientists like Max Born. Next to Jordan, probably only Werner Heisenberg, famously denounced in the SS newspaper Das Schwarze Korps as a "white Jew," was subjected to fiercer and more consistent attack from deutsche Physik. ${ }^{24}$

Meyer-Abich was perhaps under even more political scrutiny than Jordan: an attempt at gaining a professorial chair in Jena in 1936 had failed in the face of fierce opposition by virulent Nazi racial theorists who dominated the university's faculty; they claimed that holism ran contrary to "scientific" racial theory. These powerful opponents had an even more formidable ally in the form of official Nazi Party ideologist Alfred Rosenberg and his office, which attacked holism in confidential Party journals as a "cunning trick of Roman Catholic science" aimed at undermining "German factual research, exact science, and the foundations of our racial theory"; MeyerAbich was its "chief apostle." Jordan and Meyer-Abich's "mutual effort in service of German science," as Jordan termed the Physis project in a December 1941 letter, was forged from their long years as ideological outcasts. ${ }^{25}$

\footnotetext{
${ }^{23}$ As Mark Walker writes, deutsche Physik, sometimes termed "Aryan physics," was a "political movement composed of scientists using the rhetoric of science": Mark Walker, Nazi Science: Myth, Truth, and the German Atomic Bomb (New York: Plenum, 1995), p. 13. On deutsche Physik see also Alan D. Beyerchen, Scientists under Hitler: Politics and the Physics Community in the Third Reich (New Haven, Conn.: Yale Univ. Press, 1977), pp. 79-168.

${ }^{24}$ For criticisms of deutsche Physik see, e.g., Jordan, Physikalisches Denken in der neuen Zeit (cit. n. 9), pp. 7-9, 56-59. Jordan and his works were repeatedly denounced in the house journal of the deutsche Physik movement, the Zeitschrift für die Gesamte Naturwissenschaft (Journal for All Natural Sciences). See, e.g., Rembert Ramsauer, rev. of Pascual Jordan, Physikalisches Denken in der neuen Zeit, Zeitschrift für die Gesamte Naturwissenschaft, 1935, 1:342-343; and Hugo Dingler, "Die 'Physik des 20. Jahrhunderts': Eine prinzipielle Auseinandersetzung (zu einem Buche von P. Jordan)," ibid., 1937, 3:321-335. At one point, Jordan was even denounced to the Reich Education Minister; see Karl Lothar Wolf to Franz Bachér (Reich Education Ministry), 10 Oct. 1934, Bundesarchiv, Berlin-Lichterfelde, R 4901/24866, B1. 13. On the Heisenberg affair see Beyerchen, Scientists under Hitler, pp. 156-163; and Walker, Nazi Science, pp. 130-138.

${ }^{25}$ Jordan to Meyer-Abich, 27 Dec. 1941, Nachlass Meyer-Abich, Ba 38. On the views of the Jena racial theorists regarding holism see Amidon, "Adolf Meyer-Abich, Holism, and the Negotiation of Theoretical Biology" (cit. n. 2), pp. 364-365. For the criticisms from Rosenberg and his subordinates see "Der Holismus (Ganzheitslehre)," Mitteilungen zur Weltanschaulichen Lage, 27 Nov. 1936, 41(2), rpt. in Projectgruppe "Volk und Gesundheit," ed., Volk und Gesundheit: Heilen und Vernichten im Nationalsozialismus (Tübingen: Tübinger Vereinigung für Volkskunde, 1982), pp. 40_44.
} 


\section{“GERMANY'S RENEWAL” AND BIG SCIENCE}

Friendly ties now firmly established, in late 1941 Jordan and Meyer-Abich began to conceive of a larger strategy for Physis. In this greater vision, the journal itself would be accompanied by a private campaign aimed at "enlightening" certain Nazi leaders as to the pernicious - even traitorous - impact of the deutsche Physiker on the German war effort. (Naturally, "true" German science had proved its worth on the battlefield.) With their enemies smashed and exposed as frauds, Jordan and Meyer-Abich hoped that a grateful regime would then grant them free rein to determine science policy in the new "Greater German Reich." Physis would reap the rewards, emerging as a leading interdisciplinary scientific journal in "German-led" Europe.

Kicking off this campaign was a September 1941 article by Jordan in the cultural-political periodical Deutschlands Emeuerung (Germany's Renewal) titled "Science in Revolution." 26 In it, Jordan not-so-subtly derided "egotistical strivers who attempt to hide their own lack of scientific achievement through utter busybodyness [äußere Gschaftelhuberei]," a thinly veiled shot at the deutsche Physiker. ${ }^{27}$ Meanwhile, he proudly proclaimed that true scientific research was an "expression of the "will to power' [Wille zur Macht]," which inevitably led to the "development of powerful military technology [waffentechnischen Machtentfaltung]." His Nazi bona fides well established, Jordan then proceeded to outline a vision of science operating on an industrial scale - what would later be termed "big science." The size, scope, and breadth of modern scientific problems, as Jordan wrote, increasingly exceeded the "power and possibilities" of an individual researcher working on his own. Future research would require massive teams of scientists from various fields to work together on a single project in large, dedicated institutes - or, in Nazispeak, "deploy[ing] the forces of various fields in comradely group-like poolings [die Kräfte verschiedenster Fachgebiete in kameradschaftlicher gruppenmäßiger Zusammenfassung einzusetzen].” In practice, Jordan noted, this "necessity" had already begun to "assert itself." 28 One wonders whether the megalomaniacal atmosphere of "Greater Germany" inspired Jordan to amplify his vision: Did he think that grandiosity would appeal to the Nazis?

Meyer-Abich was particularly taken with a question raised in the last section of Jordan's essay: Who would lead these massive big science-style research institutes, and who would choose what to investigate? It was crucial that those at the top be truly visionary; otherwise, the funds, manpower, and equipment invested would be wasted. Jordan was sketchy on the details, but he seemed to envision some governmental authority that would be responsible for identifying "genius individuals." These brilliant luminaries would then be provided with the necessary personnel and funding, thereby making it "as easy as possible for leading [führend] minds" to "attack" the problems that they saw as critical. ${ }^{29}$ Such a shift, both "necessary for the present condition of natural science" and made "possible through National Socialism," would lead "not to constric-

\footnotetext{
${ }^{26}$ On Deutschlands Emeuerung see George L. Mosse, The Crisis of German Ideology: Intellectual Origins of the Third Reich (New York: Schocken, 1964), p. 224; and Johannes Leicht, "Deutschlands Erneuerung," in Handbuch der Antisemitismus: Judenfeindschaft in Geschichte und Gegenwart, ed. Wolfgang Benz, 8 vols., Vol. 6: Publikationen (Berlin: De Gruyter, 2013), pp. 145-146.

${ }^{27}$ Pascual Jordan, "Naturwissenschaft im Umbruch," Deutschlands Emeuerung, 1941, 25:452-458, on p. 455. Klaus Hentschel posits that this passage "hints at resentment" against Jordan's former collaborator Heisenberg. This is incorrect; the statement is aimed at the deutsche Physiker, as Jordan's letters to Meyer-Abich make clear. Moreover, while Jordan and Heisenberg were not close, Jordan had immense respect for Heisenberg's scientific abilities. See Klaus Hentschel, ed., Physics and National Socialism: An Anthology of Primary Sources (Boston: Birkhäuser, 1996), pp. 268-274, on p. 272.

${ }^{28}$ Jordan, "Naturwissenschaft im Umbruch," pp. 453, 456, 457. Ironically, Jordan was unaware how prescient this statement truly was; even as he was writing, his theoretical plan for scientific organization on the industrial level was being realized by American scientists working on the Manhattan Project.

${ }^{29}$ Ibid., pp. 457-458. Note the militaristic terminology, chosen to appeal to Nazi propagandists.
} 
tion but, on the contrary, to the higher freedom of the genius." ${ }^{30}$ In a letter to Meyer-Abich, Jordan elaborated on the article's purpose:

From the outset, I avoided going into all too delicate things in my article - one first has to attempt to develop a certain foundation of trust for cooperation between science and the present-day [i.e., Nazi] state [eine Zusammenarbeit Wissenschaft-heutiger Staat]. My struggle [Mein Kampf], which I have led now for years, aims at its core straight at this problem: to maintain untouched the responsible freedom of the researcher, not letting it be marred through deference to the nonscientific thought of the day. Therefore my fanatical fight against that clique that claims, for example, that relativity theory must be judged from ideological [weltanschauliche] viewpoints - instead of from the alternative, to be pursued imperturbably: "true or false"! I am glad that in your so concise and trenchant formulation you describe exactly why we German physicists must fight so hard against the scientifically impotent yet externally so powerful and influential group that concentrates itself around the notorious "Zeitschrift gegen die gesamten [sic] Naturwissenschaften." I find it difficult to hide my temper or my gall when I think about these gangsters of science.

According to Jordan, scientists needed to present the state with a palatable alternative in order to defeat deutsche Physik (and presumably the racial theorists): "I hold it . . . to be absolutely necessary to finally offer from physics a positive program of scientific renewal [Wissenschaftserneuerung] in the National Socialist sense-otherwise impostors and traffickers in professorships [Hochstapler und Lehrstuhl-Schieber] . . . with their campaign of defamation directed against German science will always remain on top." ${ }^{31}$ This letter is perhaps the clearest expression of the goals behind the Physis campaign - amazingly, despite eight years of personal attacks from Party elements, Jordan still believed that he could turn the regime to his advantage by "working towards the Führer." Jordan held out hope that, if he demonstrated the grand scope of his scientific vision, the regime would then strike down the "scientific gangsters" of deutsche Physik and instead implement his program of big science-style research installations across "German-led Europe." As he put it in a 1942 letter to Meyer-Abich: "I have the impression now that the wind is gradually becoming more favorable, and so I hope that after the long years of public defamation of my field as such and my person in particular, at last to soon find . . . more favorable working conditions." ${ }^{32}$

\section{A CAMPAIGN OF INTRIGUE}

The article in Deutschlands Emeuerung proved to be a turning point in Jordan and MeyerAbich's "collaborative effort[s]." In late September, the two met again in Bremen to discuss a

\footnotetext{
${ }^{30}$ Ibid., p. 458. This envisioned plan closely resembles the "Harnack principle," which remains the basis of the Max Planck Society even today: find brilliant individuals around whom to build an institute and give them the funds to do whatever research they like.

${ }^{31}$ Jordan to Meyer-Abich, 22 Sept. 1941, Nachlass Meyer-Abich, Ba 38, pp. 1-2 (emphasis in original). "Zeitschrift gegen die gesamten [sic] Naturwissenschaften" ("Journal Opposed to All Natural Sciences") is a play on the title of the house journal of deutsche Physik, the Zeitschrift für die Gesamte Naturwissenschaft (Journal for All Natural Sciences).

32 Jordan to Meyer-Abich, 29 Sept. 1942, Nachlass Meyer-Abich, Ba 38. Jordan was not the only physicist who used these types of arguments against the deutsche Physiker. Heisenberg, for example, published an article arguing along similar lines in 1943. See Werner Heisenberg, "Die Bewertung der 'modernen theoretischen Physik," Z. Gesam. Naturwiss., 1943, 9:201-212. And the German Physical Society highlighted the military applications of physics in its successful wartime campaign against deutsche Physik. See Beyerchen, Scientists under Hitler (cit. n. 23), pp. 183-191.
} 
new possibility. ${ }^{33}$ As it happened, Meyer-Abich was friends with one Heinrich Kunstmann, a naturopathic doctor and midlevel Party functionary in Hamburg, who himself was a longtime friend of the high-ranking Nazi leader Gustav Adolf Scheel, Reich Student Leader and Gauleiter (regional Party leader) of Salzburg. The plan hinged on leveraging this fortuitous network of personal friendships: Meyer-Abich and Jordan would use Kunstmann as an intermediary to send a denunciation directly to Scheel..$^{34}$ They could not mail the letter, because Jordan was denouncing one of Scheel's chief lieutenants, Fritz Kubach, and the risk that Kubach himself would intercept it would presumably have been far too high. Kubach was an SS member in charge of scientific matters in Scheel's Reich Students League, as well as one of the editors of the infamous house journal of deutsche Physik, the Zeitschrift für die Gesamte Naturwissenschaft. ${ }^{35}$ The letter would then carry the extra weight of endorsement from a close friend, and there would be no chance of its being intercepted by a stray supporter of deutsche Physik in the Party bureaucracy.

Jordan sent his denunciation to Kunstmann in November 1941. Writing both "as a representative of German science and as a National Socialist and SA-Mann," Jordan portrayed himself as acting out of concern for Scheel's best interest. Since 1933, he asserted, the "clique" of deutsche Physik had been able in an "astonishing manner" to "misuse by methodical deception for their own goals no small number of honest anti-Semitic Party members [Parteigenossen]" in a campaign of "scientific sabotage." Against this, good German physicists, who were occupied with "productive work" and had "no time for intrigue, .. . stood powerless for years." But now, with Germany at war, this clique's malicious activities were no longer negligible; scientific sabotage was "cross [ing] the border ... into Wehrmacht sabotage." For this reason, "circles in aeronautics and in the arms industry" had made a decision to mop up the affair. ${ }^{36}$ Scheel, wrote Jordan, had an inherent interest in the matter, as his loyal lieutenant Kubach was one of those who had been deceived, letting "all warnings sent his way from honorable comrades in the Party, the SA, and the SS go unheeded." If Scheel did not "induce as soon as possible a visible, firm distancing of comrade Kubach" from the forces of deutsche Physik, Kubach's "incrimination" in the "imminent ... winding up" of the case would be unavoidable, and Scheel himself could be implicated by association. Jordan was thus "convinced that the Reich Student Leader would be highly grateful if he could be supplied in good time with detailed information" on the situation. ${ }^{37}$

\footnotetext{
${ }^{33}$ Jordan to Meyer-Abich, 26 Oct. 1941, Nachlass Meyer-Abich, Ba 38. The Bremen meeting probably took place on 29 Sept.; see Jordan to Meyer-Abich, 17 Sept. 1941, 22 Sept. 1941, 26 Oct. 1941, 27 Oct. 1941, Nachlass Meyer-Abich, Ba 38.

34 On Kunstmann (1900-1964) see Michael Grüttner, "Kunstmann, Heinrich," in Biographisches Lexikon zur nationalsozialistischen Wissenschaftspolitik (Heidelberg: Synchron Wissenschaftsverlag, 2004), p. 105. On Scheel (1907-1979), who organized the deportation of Jews in occupied Alsace in 1940-1941, see Birgit Arnold, “ "Deutscher Student, es ist nicht nötig, daß Du lebst, wohl aber, daß Du Deine Pflicht gegenüber Deinem Volk erfüllst': Gustav Adolf Scheel, Reichsstudentenführer und Gauleiter von Salzburg," in Die Führer des Provinz: NS-Biographien aus Baden und Württemberg, ed. Michael Kißener and Joachim Scholtyseck (Konstanz: Universitätsverlag Konstanz, 1997), pp. 567-594. Kunstmann and Scheel probably became acquainted at the University of Heidelberg in the early 1930s. See ibid., pp. 573-574; and Grüttner, "Kunstmann, Heinrich," p. 105.

35 On Kubach (1912-1945) see Michael Grüttner, "Kubach, Fritz," in Biographisches Lexikon zur nationalsozialistischen Wissenschaftspolitik, p. 102. According to Beyerchen, it was known in physics circles in the 1930s that Scheel evidently "did not share [Kubach's] infatuation” with deutsche Physik; perhaps this is why Jordan thought Scheel could be convinced to turn on one of his deputies. See Beyerchen, Scientists under Hitler (cit. n. 23), p. 162.

${ }^{36}$ Jordan to Heinrich Kunstmann (copy), 26 Nov. 1941, Nachlass Meyer-Abich, Ba 38, pp. 1-2 (emphasis in original). Jordan is referring here to the detailed memorandum composed by the leadership of the German Physical Society in the fall of 1941, which spelled out the damage dealt to Germany by deutsche Physik. This memo was sent to the Reich Education Ministry and the Reich Aviation Ministry in early 1942 and ultimately led to the downfall of deutsche Physik. See Beyerchen, Scientists under Hitler, pp. 183-188. Jordan knew about this further intrigue; see Werner Heisenberg to Jordan, 31 July 1942, Nachlass Heisenberg, Archiv der Max-Planck-Gesellschaft, Berlin, III. Abt., Rep. 93, Nr. 1968/3.

${ }^{37}$ Jordan to Kunstmann (copy), 26 Nov. 1941, pp. 1-2 (emphasis in original).
} 
In letters to Meyer-Abich, Jordan described the grander aims of the denunciation. Simply "neutralizing" Kubach was just the start; the ultimate goal would be for Jordan to "attain a positive advisory function with Scheel regarding natural scientific questions" - that is, to take Kubach's place in Scheel's inner circle. With the backing of an ambitious rising star in the Party, Jordan would have immense power to organize science as he saw fit in the "new Germany." In this position, Jordan would be able to realize and institutionalize the program of big science sketched in his Deutschlands Emeuerung article and expanded on in Physis. Sending along a copy of that article - in case Meyer-Abich wanted to have a "pre-orientating consultation" with Kunstmann before the denunciation arrived-Jordan cautioned his friend, revealingly noting that the essay "would be best read on the part of Kunstmann not without a certain commentary on your partthe many trains of thought therein only hinted at in telegraphic style [telegrammstilartig] will really be only fully understandable in connection with the synthesis efforts [Synthese-Bestrebungen] pursued in Physis. ${ }^{38}$ From the start, the campaign of intrigue, the new journal, and the vision of Europe-wide big science, suitably Nazified to secure financial support, were part of a unified effort by Jordan and Meyer-Abich to twist the regime in their favor. And in a sign of what was to become of Physis itself, this attempt at intrigue failed miserably. Kunstmann declined to send Jordan's denunciation on to Scheel directly, making only a small remark about the matter in a longer letter to Scheel. Jordan feared that this would not serve to convince Scheel of the "nature and severity" of Kubach's compromised position. His fears were borne out, for it seems that Kubach heard tell of the intrigue and fired off a letter to Kunstmann, shutting down the conspiracy for good. ${ }^{39}$

\section{THE JOURNAL ITSELF}

The mouthpiece for Jordan and Meyer-Abich's grand vision - the journal Physis itself-faced entrenched opposition even before the first issue appeared in print. The first voice of opposition was perhaps the most surprising: even Meyer-Abich's publisher at Hippokrates-Verlag, one Herr Marquardt, seems to have viewed the venture as risky. ${ }^{40} \mathrm{~A}$ friend to whom Marquardt sent an advance copy of the Physis issue in June 1942 responded with seven pages of complaints-largely scientific, but some also ideological - about the journal's contents. This anonymous friend of the publisher was particularly incensed by Hans Petersen's article on philosophy of biology, finding it unscientific; he feared that such publications would "damage ... the reputation of the publisher." Meyer-Abich was able to assuage Marquardt's fears by spinning the detailed critique as an indication that the provocative statements had been well digested: "If Physis is capable of making someone that furious, then I take it as a good sign that we are on the right path!"41

More threatening to the journal's future, though, was the trouble Physis evidently faced in receiving approval from certain Nazi authorities. The issue hinged on the question of "paper allocation" (Papierbewilligung, Papierzuteilung, or Papiergenehmigung) - that is, the provision of

\footnotetext{
${ }^{38}$ Jordan to Meyer-Abich, 27 Oct. 1941, 31 Oct. 1941, p. 1, Nachlass Meyer-Abich, Ba 38. Jordan also listed one final piece of the puzzle: his new book Die Physik und das Geheimnis des organischen Lebens (Physics and the Secret of Organic Life), which appeared in fall 1941. Given its "certain programmatic importance" for their campaign, as Jordan put it, it was reviewed - glowingly, of course - by Meyer-Abich on Jordan’s express request in the 1942 Physis issue. See Jordan to Meyer-Abich, 27 Oct. 1941, Nachlass Meyer-Abich, Ba 38; Pascual Jordan, Die Physik und das Geheimnis des organischen Lebens (Braunschweig: Vieweg, 1941); and Adolf Meyer-Abich, rev. of Pascual Jordan, Die Physik und das Geheimnis des organischen Lebens, Physis, 1942, 1:97101.

${ }^{39}$ Jordan to Meyer-Abich, 27 Dec. 1941, Nachlass Meyer-Abich, Ba 38 ("nature and severity"). That Kunstmann received a letter from Kubach is noted in Jordan to Meyer-Abich, 19 Feb. 1942, Nachlass Meyer-Abich, Ba 38.

${ }^{40}$ It remains unclear how much of the company archive of the former Hippokrates-Verlag survives today. The publisher was bought by Thieme Verlagsgruppe in 1980, and an inquiry to Thieme on the matter was inconclusive.

41 “Polemik: 'Unbekannt' gegen Physis" ("Polemic: 'Anonymous' against Physis") [this title written in Meyer-Abich's handwriting], entry 23 June 1942; and Meyer-Abich to Marquardt, 4 Aug. 1942, p. 1: Nachlass Meyer-Abich, Bd 38.
} 
the physical stock on which the issue would be printed. The war indeed brought about a serious shortage of paper in Germany, but the paper rationing measures that were introduced quickly became an additional tool for censorship - tellingly, they were based out of the Propaganda Ministry. While there was a list of works officially banned by the Nazi state, during the war far more books were simply denied paper allocation for very nebulous reasons, leaving the authors (or editors) in the dark as to how - or even if - they had run afoul of Nazi censorship laws. ${ }^{42}$ MeyerAbich, as the managing editor of Physis, was in charge of getting the issue through to print. A savvy political operator, he cleverly emphasized the journal's international audience in his plea for Physis. This dazzled Jordan and apparently impressed the necessary Nazi functionaries as well, as they approved the application; with the road clear, Meyer-Abich and Jordan hoped to see the first issue in print in the fall of $1941 .^{43}$

Despite Jordan and Meyer-Abich's optimistic hopes for quick publication in 1941, the first issue of Physis appeared only after a relatively long delay, in late June or early July 1942. Perhaps there was more behind-the-scenes opposition to the journal, or maybe the delay was simply due to the war's impact on the already slow-moving publishing industry. Whatever the reason for the holdup, the final product was a curious beast. Given its role as the vehicle through which Jordan and Meyer-Abich aimed to cement regime support for their science, the journal contained a strange mixture of "normal" scientific articles alongside contributions attempting in varying ways to "work towards the Führer." An essay by the Dutch botanist B. H. Danser arguing for a typological species concept rather than a phylogenetic model, for example, could easily have been printed in a contemporary journal on theoretical biology. Similarly, the brief posthumous essay by the zoologist and anatomist Hans Böker, a description of a biological research trip to the Zapata swamp in Cuba, resembles other natural histories of its day. Neither of these articles displays discernible ideological influence. Meyer-Abich's opening polemic on synthesis is more characteristic. The essay is filled with fiery antimechanistic rhetoric but remains free of overt paeans to Nazism. Yet in an extended metaphor toward the end, Meyer-Abich strikingly chose to characterize his beloved Ganzheit as a "bridge" across which "all" efforts toward scientific synthesis necessarily needed to "march." With German troops parading across Europe, this choice of phrase would not have been missed by readers. ${ }^{44}$ (See Figure 3.)

Meyer-Abich's second essay was far less subtle. Originally delivered in May 1941 as a lecture to the advisory board (Beirat) of the newly reestablished Colonial Institute at the University of Hamburg-a nexus of Nazi colonial fantasies in Africa - it presupposed the "obvious" fact that a victorious Germany would soon reacquire the colonies it had lost in the Treaty of Versailles. Meyer-Abich urged eager colonizers to avoid "the capitalist way of doing business" practiced "unrestrainedly" in the "English-American possessions and zones of influence," which only led to "overexploitation" and the destruction of the soil base. Instead of immediately looking to turn the biggest possible profit, American-style, Nazi colonists would do well to heed and fund the research of good German tropical scientists (like himself) and work more appropriately and

\footnotetext{
42 See Paul Hövel, "Die Wirtschaftsstelle des deutschen Buchhandels, Berlin 1935 bis 1945: Ein Augenzeugenbericht," Buchhandelsgeschichte: Aufsätze, Rezensionen und Berichte zur Geschichte des Buchwesens, 1984, no. 1, pp. B1-B16. On paper allocation see also Jan-Pieter Barbian, Literaturpolitik im "Dritten Reich": Institutionen, Kompetenzen, Betätigungsfelder (Frankfurt am Main: Buchhändler-Vereinigung, 1993), pp. 238-242.

${ }^{43}$ Meyer-Abich's plea for the first Physis issue is apparently lost, but it likely resembled a very similar endorsement for the abortive second issue; see Adolf Meyer-Abich, "Betrifft: Papiergenehmigungsantrag für 'Physis'-Heft 2/3," 10 Jan. 1943, Nachlass MeyerAbich, Bd 38. For Jordan's responses to Meyer-Abich's efforts see Jordan to Meyer-Abich, 5 July 1941, 17 Aug. 1941, Nachlass Meyer-Abich, Ba 38. See also Meyer-Abich to Neergaard (copy), 12 June 1941, p. 2, Nachlass Meyer-Abich, Ba 58.

${ }^{44}$ Benedictus Hubertus Danser, "Typologie und Phylogenie," Physis, 1942, 1:52-63; Hans Böker, "Die Gran Cienaga de Zapata (Cuba)," ibid., pp. 80-84; and Meyer-Abich, "Naturwissenschaftliche Synthese" (cit. n. 1), p. 12.
} 


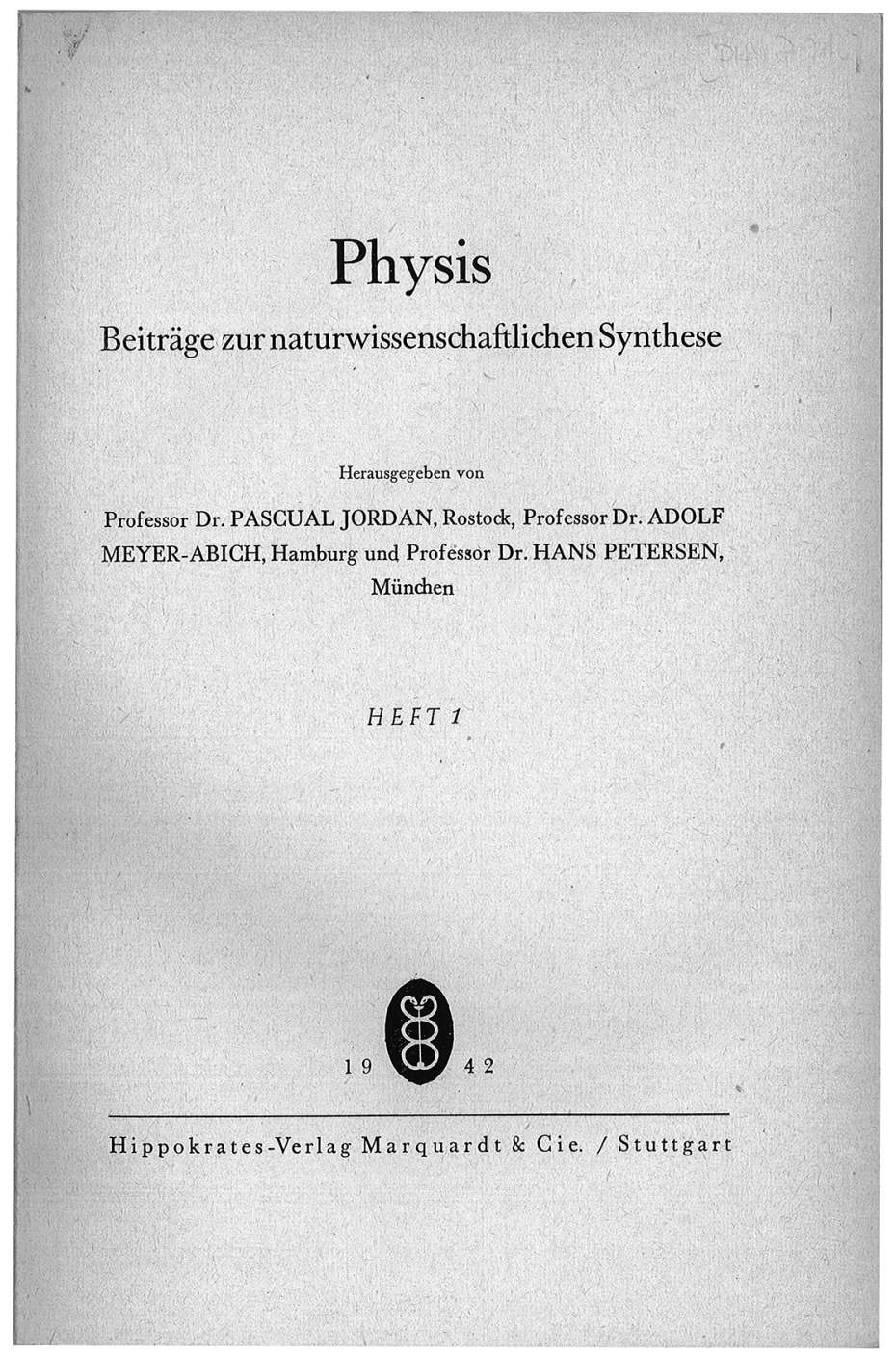

Figure 3. The title page of the first issue of Physis, published in June or July 1942. The names of the three editors are listed alphabetically. Reproduced courtesy of Georg Thieme Verlag.

sustainably with the unique landscape of the tropics. As he concluded, scientific research and practical colonial administration would need to work hand in hand if "the development of our future colonies should take place with the same élan that characterizes all large undertakings of the Greater German Reich." 45

Visions of German geopolitical grandeur were similarly present in Meyer-Abich's review of the Swedish-born Swiss doctor Kurt von Neergaard's book Die Aufgabe des 20. Jahrhunderts (The Task of the Twentieth Century). Neergaard's work envisioned a Spenglerian world in which

\footnotetext{
45 Adolf Meyer-Abich, "Aufgaben der naturwissenschaftlichen Forschung in den Kolonien,” Physis, 1942, 1:85-95, on pp. 90, 94. On the Colonial Institute and Nazi imperial fantasies in Africa see Karsten Linne, Deutschland jenseits des Äquators? NSKolonialplanungen für Afrika (Berlin: Ch. Links, 2008), pp. 54-56.
} 
revolutions in science were necessarily coupled with political upheaval. The conclusion, which ruminated on how Switzerland would fit into the "political transformations of our time" - namely, a European continent ruled by Germany-was singled out by Meyer-Abich for particular praise. Making thinly veiled reference to the popular sympathy among the Swiss for maintaining their traditional neutrality and democracy, Meyer-Abich noted that he hoped the book would be "understood and appreciated by more of [Neergaard's] countrymen," for it would then be "a lot easier for Switzerland to sincerely say yes to the new Europe being born out of the tempests and thunderstorms of this world war." ${ }^{46}$ Here he was in lockstep with the Nazi line on the subject, which envisioned that Switzerland would eventually join the Reich - whether willingly or by force.

Jordan used rhetorical strategies similar to those of Meyer-Abich. He was not afraid to proclaim in his authorial byline that he was "currently [with the] Wehrmacht," thereby implicitly demonstrating his allegiance to the regime. ${ }^{47}$ Yet as with Meyer-Abich, Jordan's first article, outlining how the successes of quantum mechanics could be exported to the biological realm in what he termed "quantum biology," was largely standard scientific fare. ${ }^{48}$ The second contribution, though, exemplified the way in which ideology could find its way into Physis - and into the plan for Europe-wide big science - as it was written specifically to pique the curiosity of wellpositioned Nazi power brokers. Titled "Future Tasks for Quantum Biological Research," it expanded on Jordan's article in Deutschlands Emeuerung, outlining a detailed plan for a massive group of research institutes to investigate Jordan's quantum biology - essentially prototyping his vision of big science. The "research center" envisioned was so costly and ambitious that "its realization would certainly presuppose the German victory as already achieved," so it would "stand after the German victory as a symbol and representation of the unlimited means of power [Machtmittel] of the new Reich." ${ }^{49}$ In charge would be a Führerinstitut, or leading institute, conforming to the Nazi Führer principle that a leader should be found in every area. ${ }^{50}$ At the end, Jordan slyly tied his proposed institute to another of the Nazis' favorite bugbears, cancer, noting that all quantum biological research opened "new possibilities of attack against the cancer problem."

This wide spectrum of articles makes the deeper designs for Physis clear: Jordan and MeyerAbich aimed to create a leading (and the analogy to the Führer was intended) interdisciplinary, international, scientific organ, in the vein of Nature or the German Die Naturwissenschaften, that would institutionalize Jordan's vision of big science in the "new Europe." Demonstrating the quality, loyalty, and military value of German science to the Nazi state, Physis was to be a vehicle through which Jordan and Meyer-Abich could pull in financial support-and protection - for their monumental plan for a Europe-wide scientific enterprise operating on an industrial scale under German leadership. Hence the odd blend of "normal" scientific papers with

\footnotetext{
${ }^{46}$ Kurt von Neergaard, “Selbstanzeige: Die Aufgabe des 20. Jahrhunderts," Physis, 1942, 1:101-103, on p. 103 (this is a précis of the book that preceded the review); and Adolf Meyer-Abich, rev. of Kurt von Neergaard, Die Aufgabe des 20. Jahrhunderts, ibid., pp. 103-105, on p. 104.

47 Jordan, "Begriff und Umgrenzung der Quantenbiologie" (cit. n. 21), p. 13; and Jordan, “Zukunftsaufgaben quantenbiologischer Forschung” (cit. n. 6), p. 64.

${ }^{48}$ The only exception is Jordan's mention of the "amplifier theory of the organism": Jordan, "Begriff und Umgrenzung der Quantenbiologie," pp. 17-18. Norton Wise points out that this theory is based on a Nazi analogy; see Wise, "Pascual Jordan" (cit. n. 8), pp. 237-240.

${ }^{49}$ Jordan, "Zukunftsaufgaben quantenbiologischer Forschung" (cit. n. 6), p. 66. The article was intended to impress a "Reich office in Berlin ... [with] great authority": Jordan to Meyer-Abich, 3 Nov. 1941, Nachlass Meyer-Abich, Ba 38.

${ }^{50}$ Jordan, “Zukunftsaufgaben quantenbiologischer Forschung," p. 67. Ironically, a version of Jordan's planned institute would eventually be realized in postwar East Germany. See Richard H. Beyler, "Targeting the Organism: The Scientific and Cultural Context of Pascual Jordan's Quantum Biology, 1932-1947,” Isis, 1996, 87:248-273, esp. pp. 270-271.

${ }^{51}$ Jordan, "Zukunftsaufgaben quantenbiologischer Forschung," pp. 78-79. On the Nazi obsession with cancer research see Robert Proctor, The Nazi War on Cancer (Princeton, N.J.: Princeton Univ. Press, 1999).
} 
grandiose blueprints for Nazified big science; such an ambitious undertaking required "working towards the Führer" if it hoped to fulfill these lofty aspirations.

\section{THE FAILED SECOND WARTIME ISSUE}

The reaction to Physis in the German scientific and popular press was generally positive. Commentators praised the journal's forceful drive to find unity in the seemingly disparate fields of science as a goal worthy of pursuit. "Scientific synthesis,' this is really what we are lacking today!" wrote Franz Wetzel in the popular scientific magazine Natur und Kultur. Reviewers like Wetzel latched on to the journal's ambition, praising Jordan's vision of big science: "it is to be hoped that Jordan's lavish institute and [scientific] organization plan will be promptly realized after the war." Even those reviewers who noted that realization of Jordan's hopes was "still very much in the future" were willing to concede that the comprehensive plan for a research installation was "very ideal." An unsigned review in the Frankfurter Zeitung summed up the general response to the first issue of Physis, endorsing the extensive scientific plans of the journal's editors: "It is a remarkable sign of the vigor of German science that in the middle of our difficult struggle, the first issue of a new journal can appear that ... wants to serve far-reaching future goals." ${ }^{52}$

Fortified by this favorable response, Meyer-Abich and Jordan immediately set to work recruiting articles for the second issue of Physis, planned for publication in late 1942 or early 1943. As Jordan remained otherwise occupied in the Luftwaffe, Meyer-Abich again took the lead, soliciting articles from his extensive network of scientific correspondents across "German-led" Europe. A heavily annotated - and presumably nearly final-outline for the planned second issue survives, and it epitomizes just how tightly Physis had become bound to elements of the Nazi enterprise. The new issue was to include, for example, an article on forestry from Kurt Friedrichs, a professor at the newly founded "Reich University of Posen" in occupied Poland - a university designed by the Nazis to be the model institution for the newly annexed Eastern territories. ${ }^{53}$ Most telling, though, was a contribution from a personal friend of Meyer-Abich, SS Colonel Joachim Mrugowsky, head of the Waffen-SS Hygiene Institute in Berlin. To be titled "Hygiene Research in the Wake of War," the article would have appeared in a new subsection of Physis called "War and Research." Mrugowsky's institute was a place where human experimentation on concentration camp prisoners - with often-fatal results-was accepted practice, and from the title of his article it is clear that he would have been drawing on this type of research. Physis would thus have been just one step removed from the regime's deepest crimes. ${ }^{54}$ (See Figure 4.)

\footnotetext{
${ }^{52}$ Franz Wetzel, "Physis: Beiträge zur naturwissenschaftlichen Synthese," Natur und Kultur, 1942, 39(10); M. Braun, "Physis, Beiträge zur naturwissenschaftlichen Synthese," Süddeutsche Apotheker-Zeitung, 1942, 82:288; and "Für die Einheit der Naturwissenschaften," Frankfurter Zeitung, 18 July 1942.

${ }^{53}$ Meyer-Abich, outline for "Physis H. 2/4," undated (likely Nov. or Dec. 1942), Nachlass Meyer-Abich, Bd 38. On the Reichsuniversität Posen see, e.g., Helmut Wilhelm Schaller, Die "Reichsuniversität Posen" 1941-1945: Vorgeschichte, nationalsozialistische Gründung, Widerstand und polnischer Neubeginn (Frankfurt am Main: Lang, 2010).

${ }^{54}$ Meyer-Abich, outline for "Physis H. 2/4," p. 1. Apparently no manuscript copy of Mrugowsky's article exists. While it does not seem that Jordan ever met Mrugowsky, he was nevertheless "very interest[ed]" in meeting the SS Colonel "someday" and "perhaps taking a look at his institute": Jordan to Meyer-Abich, 3 Oct. 1944, Nachlass Meyer-Abich, Ba 1. I thank Kevin Amidon for his help in locating this letter. Mrugowsky was ultimately sentenced to death by an American military court for crimes against humanity at the 1946-1947 Doctors' Trial in Nuremberg and was executed in 1948. Meyer-Abich submitted an affidavit to the American military court in support of Mrugowsky, claiming that his SS Hygiene Institute was a "purely scientific research establishment." See Adolf Meyer-Abich, "Affidavit concerning Mrugowsky's belief in 'Holism' and other views," Document Joachim Mrugowsky No. 106, dated 1 Mar. 1947, pp. 1-5, on p. 5, Nuremberg Military Trial 1 (Medical Case: United States of America v. Karl Brandt et al.), available online at http://nuremberg.law.harvard.edu/documents/787-affidavit-concerning -mrugowskys-belief. For more on Mrugowsky see Florian Bruns, Medizinethik im Nationalsozialismus: Entwicklungen und Protagonisten in Berlin (1939-1945) (Stuttgart: Steiner, 2009), pp. 131-166; and Amidon, "Adolf Meyer-Abich, Holism, and the Negotiation of Theoretical Biology" (cit. n. 2), pp. 365-366.
} 


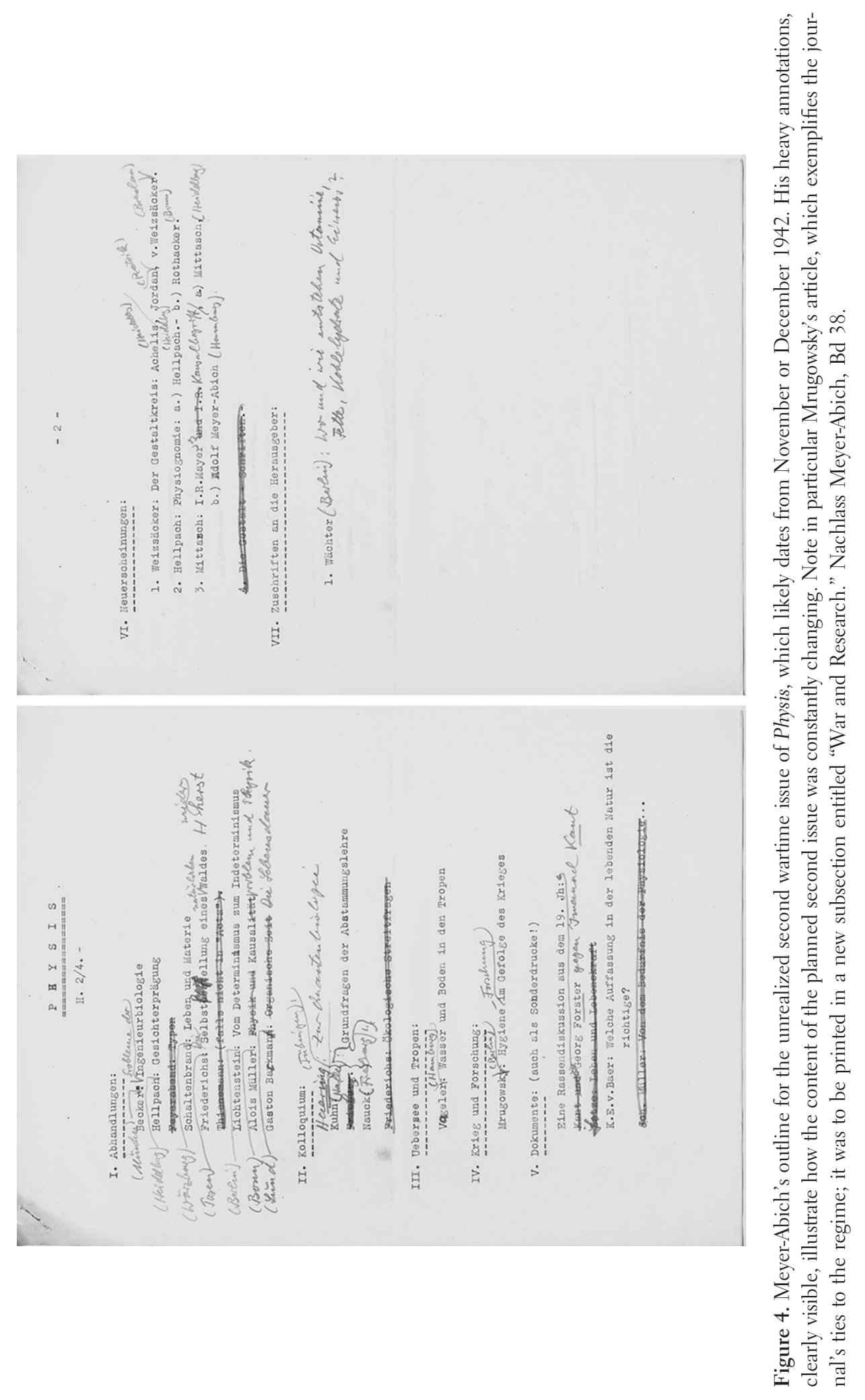


Despite this new connection to Mrugowsky, efforts to bring the second issue of Physis to print began to stumble in December 1942, just as the tide of the war began to turn against Germany. That month, Marquardt informed Meyer-Abich that the paper allocation request for the new issue had been rejected and that the responsible authorities at the Propaganda Ministry said that a new application would have to wait until after the war was over. "Behind the rejection [of Physis] stand stronger forces than we thought," he added cryptically; Physis had run afoul of elements in the Party. Indeed, the deutsche Physiker had made their voices heard at the Propaganda Ministry, which had assigned one of their number to assess Physis. This referee's report was predictably damning, and he privately termed Physis "simply appalling." ${ }^{55}$ In January 1943 Meyer-Abich received more bad news: the Völkischer Beobachter, the official newspaper of the Nazi Party, had declined to review Physis and returned its review copy to the publisher. The racial theorists were up in arms as well; in March 1943 a vicious review by Lothar Stengel-von Rutkowski, professor of "racial hygiene" in Jena, appeared in their house journal, Der Biologe. It accused Meyer-Abich of being a Catholic-like missionary of an antiscientific dogma called holism: "it is the altar of wholeness [Ganzheit] upon which, if necessary, one is happily prepared to sacrifice scientific impartiality as well as natural scientific truth." ${ }^{56}$

How were Jordan and Meyer-Abich to combat these opponents? Marquardt suggested asking the Cultural Division in the German Foreign Office for an endorsement of Physis, "in view of the foreign importance of the monograph series." This tactic, emphasizing the journal's internationalism as a way to win the propaganda war in occupied and neutral states, now assumed center stage. Meyer-Abich and Jordan were certainly interested in attracting quality scientific work from outside "Greater Germany," yet these contributions were seen to be just as important for their value to the journal's reputation domestically. Jordan and Meyer-Abich's case for the journal's support from the Nazi state rested on the idea that their vision of industrial-scale big science-championed by Physis - also served the regime's propaganda aims abroad, that it would be Nazi Germany leading the future of Europe and European science. Meyer-Abich made this explicit in letters to colleagues in neutral countries like Sweden and Switzerland, bluntly asking them to arrange favorable reviews of Physis in local newspapers, which Meyer-Abich could then use as evidence of the journal's effectiveness in the war of public opinion. ${ }^{57}$

Meyer-Abich's ultimate appeal to the Foreign Office in January 1943 makes clear how Physis was tied to German hegemony on the Continent: "It is the goal of Physis to bring to print fundamental contributions of broader impact in all of the natural sciences from leading minds across German-led Europe." It was a testament to the journal's value as soft propaganda that the editors had even succeeded in recruiting articles from scientists "outside the German-led European community of states" - that is, the neutral countries - which "considering the intellectual movements unfortunately still prevalent in these lands ... has not been an easy task." Physis in this reading was a way to win the scientific elite of neutral states, who would be integrated into

\footnotetext{
55 Marquardt to Meyer-Abich, 21 Dec. 1942, 22 Dec. 1942, p. 1, Nachlass Meyer-Abich, Bd 38; and Eduard May to Hugo Dingler, 16 July 1942, p. 1, Nachlass Hugo Dingler, Correspondence, Hofbibliothek Aschaffenburg. Dingler, one of the leaders of deutsche Physik, was perhaps Jordan's biggest enemy during the Nazi period, and May was one of his chief compatriots. The report to the ministry apparently does not survive.

56 [Granz?], Werbeabteilung, Hippokrates-Verlag, to Meyer-Abich, 21 Jan. 1943, Nachlass Meyer-Abich, Bd 38 (return of review copy); and Lothar Stengel-von Rutkowski, "Physis: Beiträge zur naturwissenschaftlichen Synthese," Der Biologe, 1943, 12:90_91. Interestingly, though they despised Meyer-Abich, the racial theorists seem to have approved of Jordan's vision of big science; Rutkowski actually complemented Jordan's detailed plan for a research installation devoted to quantum biology in his review. ${ }^{57}$ Marquardt to Meyer-Abich, 22 Dec. 1942, Nachlass Meyer-Abich, Bd 38, p. 1. For letters requesting foreign colleagues to arrange favorable reviews see, e.g., Meyer-Abich to Gaston Beckman, 23 Sept. 1942, p. 2, and Meyer-Abich to Neergaard, 23 Sept. 1942, p. 1-2: Nachlass Meyer-Abich, Bd 38.
} 
the German-led big science enterprise after the war, to the German cause. One of those who had already been won over was the Swedish anatomist Gaston Beckman. How would it look, MeyerAbich asked the Foreign Office, if he had to return Beckman's "exceptional" article with the sad explanation that there simply wasn't enough paper stock to print the issue? Not only would it be personally embarrassing for Meyer-Abich, but Beckman might then choose to publish the manuscript in a British journal like Nature, a move that would push him into the Allied camp. ${ }^{58}$

Despite this paean to the dreams of Nazi propagandists, Meyer-Abich received the same response from his contact in the Foreign Office in March 1943: there simply was no paper available for printing Physis. They prepared a new application in June 1943. This time, Meyer-Abich personally traveled to Berlin to visit both the Propaganda Ministry and the Foreign Office, believing that in both places he had found "complete understanding" for the journal. The new application would be bolstered by an endorsement from the leader of the Hamburg Regional Propaganda Office (Gaupropagandaamt), Ernst Schrewe, who had evidently promised Meyer-Abich that he would support Physis's application "most urgently." 59 The application from HippokratesVerlag reiterated Physis's importance to the "self-evident assumption" that Germany needed to "keep the lead in Europe" in the natural sciences, as outlined in Meyer-Abich's January 1943 memo. Though this effort at one point seemed to be on the verge of success, in the end the application for paper was denied yet again, for reasons that remain unclear. ${ }^{60}$ Physis - and, with it, Jordan's dream of a Europe-wide system of gargantuan scientific institutes under German leadership - was for all intents and purposes dead.

\section{A FINAL ATTEMPT: PHYSIS FOR SOLDIERS?}

These repeated rebuffs coincided with a turn in the course of the war; the German army, seemingly invincible in 1941, was on the defensive in 1943. New wartime measures signaled by Joseph Goebbels's infamous "total war" speech in the Berlin Sportpalast in February 1943 led to the near-total shutdown of all activities not deemed vital to the war effort. The publishing industry was hit hard, and the prospects for Physis looked grim. As Jordan artfully put it to Meyer-Abich in March 1943, because the "external conditions [had been] so radically changed since [the German defeat at] Stalingrad," Physis would "probably only be able to be maintained on a muchreduced scale and at a much slower tempo for the time being." He tried to remain optimistic, though; with the "successful" first issue, they had defined "the name and form and the general line" and laid "solid ground" for the future. ${ }^{61}$

Jordan and Meyer-Abich's collaborators in the neutral nations, so crucial to the argument that Physis could serve as an instrument of German soft power abroad, were not so sanguine about the journal's future. With "German-led Europe" now looking like a temporary reality at best, many became skittish about lending their names to a project so clearly attached to the regime. When

\footnotetext{
${ }^{58}$ Adolf Meyer-Abich, "Betrifft: Papiergenehmigungsantrag für Physis-Heft 2/3," 10 Jan. 1943, Nachlass Meyer-Abich, Bd 38 , p. 1.

${ }^{59}$ Rudolf von Wistinghausen, Auswärtiges Amt, to Meyer-Abich, 3 Mar. 1943, Nachlass Meyer-Abich, Bd 38; and Meyer-Abich to Paul Roth, Kulturabteilung des Auswärtigen Amtes, 7 June 1943, Nachlass Meyer-Abich, Bd 38. On Schrewe see Uwe Schmidt, Nationalsozialistische Schulverwaltung in Hamburg: Vier Führungspersonen (Hamburg: Hamburg Univ. Press, 2008 ), pp. 95-106. ${ }^{60}$ Presumably Marquardt, Hippokrates-Verlag, to Paetel, Wirtschaftsstelle des deutschen Buchhandels, undated (likely June 1943), Nachlass Meyer-Abich, Bd 38, p. 1. Jordan was positive about the issue's prospects at one point in summer 1943 , but these hopes came to nothing; see Jordan to Meyer-Abich, 21 June 1943, Nachlass Meyer-Abich, Ba 38.

${ }^{61}$ Jordan to Meyer-Abich, 8 Mar. 1943, Nachlass Meyer-Abich, Ba 38. On the impact of "total war" measures on the publishing industry see Jan-Pieter Barbian, Literaturpolitik im NS-Staat: Von der "Gleichschaltung” bis zum Ruin (Frankfurt am Main: Fischer, 2010), pp. 244-250. Hippokrates-Verlag was one of 220 publishers allowed to remain open even after summer 1944. See Hans-Eugen Bühler and Edelgard Bühler, Der Frontbuchhandel 1939-1945: Organisation, Kompetenzen, Verlage, Bücher: Eine Dokumentation (Frankfurt am Main: Buchhändler-Vereinigung, 2002), pp. 76-85, esp. p. 78.
} 
Kurt von Neergaard finally responded, late in 1942, to an inquiry from Meyer-Abich about finding friendly Swiss reviewers for Physis, he urged that they "abandon" this effort entirely. Such a review, he suggested, in light of the praise in Physis for Neergaard's pro-German sympathies, would "with high probability, given the present situation, have rather unpleasant consequences even for me." In Switzerland, he wrote, even the term "Ganzheit" had been poisoned by association with Nazism. When Meyer-Abich requested that he contribute an article to the new issue, he quietly demurred. Jordan was just as toxic; Neergaard had to abandon an attempt to invite him to Zurich to lecture on quantum biology because the "political sections" in his works provoked outrage. Neergaard, a pro-German in neutral Switzerland, now feared for his own career, bluntly reminding Meyer-Abich that "the whole situation would of course be completely different if [General Erwin] R[ommel] stood in Alexandria and Stalingrad had fallen immediately." 62

With the deck now firmly stacked against them, one might suppose that Meyer-Abich and Jordan would have given up on their efforts to publish a second issue during the war. And, indeed, they let the matter rest for almost a year. Yet Meyer-Abich would not let his beloved journal vanish so easily, making one last attempt at getting it to print in fall 1944-as Allied armies advanced on the Reich from East and West. There was, it turned out, another way to get a book published that could potentially avoid the Propaganda Ministry entirely: through the Wehrmacht. The German Army had its own supply of paper, independent of the Propaganda Ministry; that supply was reserved exclusively for projects that were kriegswichtig, or crucial to the war effort. By receiving contracts directly from the Wehrmacht, publishers could both avoid some of the censorship from the Propaganda Ministry and get their works into print much more quickly. ${ }^{63}$ Books published in this manner, though, were not available to the general public in Germany or in Europe; they were instead distributed directly to the troops, as "army editions" or "field post editions" (Wehrmachtausgaben or Feldpostausgaben), through an extensive network of "front book stores" in the occupied countries. Tens of millions of books were thus provided to German soldiers. ${ }^{64}$ Amazingly, in its last incarnation Physis was to be printed as one of these special "field post editions," intended as reading material for German troops at the front.

As early as January 1944, Meyer-Abich had received word from Marquardt that paper would "probably be made available soonest" for field post editions published contractually through the Wehrmacht. Yet it was only in late September 1944 that the Wehrmacht finally placed an order for 650 copies of the first issue of Physis. As Marquardt noted, since the contract was made out in Jordan's name merely for a publication titled Physis, this field post edition could have "different contents" from the first issue of Physis - meaning that the Wehrmacht edition would become a stealth second issue of the journal. Jumping at the opportunity, Meyer-Abich activated his correspondence networks once again. The issue would have ten articles, and as it was strictly limited to 160 pages it would be printed in a smaller typeface so as to pack in more content. ${ }^{65}$ This planned Wehrmacht issue also differed from the version marketed to the Foreign Office in 1943: among the ten contributors were Meyer-Abich, Petersen, Jordan, the medical doctor Willy

\footnotetext{
${ }^{62}$ Neergaard to Meyer-Abich, 12 Oct. 1942, p. 1, Nachlass Meyer-Abich, Ba 58; and Neergaard to Meyer-Abich, 22 Dec. 1942, 23 Nov. 1942, p. 2 (the book Neergaard is referring to is Jordan's Die Physik und das Geheimnis des organischen Lebens [cit. n. 38]), Nachlass Meyer-Abich, Ba 38.

${ }^{63}$ Barbian, Literaturpolitik im "Dritten Reich" (cit. n. 42), pp. 313-315; Barbian, Literaturpolitik im NS-Staat (cit. n. 61), pp. 186-192; and Bühler and Bühler, Der Frontbuchhandel 1939-1945 (cit. n. 61).

${ }_{64}$ Bühler and Bühler, Der Frontbuchhandel 1939-1945, pp. 88-112, 125; and Barbian, Literaturpolitik im NS-Staat, pp. 189192.

${ }^{65}$ Quoted in Meyer-Abich to Joachim Mrugowsky, 18 Jan. 1944 (copy), Nachlass Meyer-Abich, Ba 55 (quoting Marquardt on paper availability); and Marquardt to Meyer-Abich, 23 Sept. 1944, Nachlass Meyer-Abich, Bd 38. Regarding the new issue see Marquardt to Meyer-Abich, 27 Oct. 1944, 8 Nov. 1944, 14 Nov. 1944, Nachlass Meyer-Abich, Bd 38.
} 
Hellpach, the chemist Alwin Mittasch, and the zoologist Kurt Friedrichs. ${ }^{66}$ Jordan's essay would have been a reprint of one of his essays from the first issue, as he was again too busy with war work to compose another piece, but most of the others were to be new. By November 1944, the paper allocation for the Wehrmacht Physis issue had finally been granted, but it received the lowest "urgency level" designation from the army, meaning that production would take months at best. ${ }^{67}$ As German armies were routed in early 1945, this bizarre final iteration of Physis perished on the vine at Hippokrates-Verlag.

The perplexing case of the Wehrmacht Physis issue prompts an obvious question: Why did Jordan and Meyer-Abich think that the average war-weary German soldier would want to read extended tracts on holism, quantum biology, or philosophy? Most field post editions marketed to soldiers and produced via Wehrmacht contracts were either standard Nazi agitprop, glorying in German victories, or escapist fiction meant for broad consumption. These types of works were also printed in much higher volume-with editions quite often numbering in the hundreds of thousands. And that raises another question: Why the extremely low print run? ${ }^{68}$ Yet even if the print run were higher, the issue was to be printed exclusively for soldiers and sent to them directly, meaning that those academics to whom Physis was marketed would not be able to obtain this new issue!

Perhaps Meyer-Abich and Jordan gave these seemingly self-evident questions little thought, simply wishing to put out a new issue of Physis however they could, not caring whom it reached. Or maybe the futile, almost absurd, attempt to continue Physis was simply a coping mechanism for Meyer-Abich, a search for normalcy from a man whose entire world was collapsing. Yet it also seems plausible that Meyer-Abich had an ulterior motive. The Wehrmacht book publishing industry was notoriously corrupt during the Third Reich; with paper stock hard to come by, underthe-table dealing and bribery predictably ensued. Moreover, cryptic remarks in one of Marquardt's November 1944 letters allude to a "shipment" sent by the publisher to neutral Switzerland under an "export declaration" signed by Meyer-Abich. ${ }^{69}$ This "shipment" did not contain copies of the Physis issue, for it had not yet been printed. But it is possible that Meyer-Abich planned to perform a similar maneuver with the 650 copies of the Wehrmacht Physis issue. With a new printed issue then safely stored in Switzerland during the Third Reich's Götterdämmerung, Physis would be ready for distribution immediately after the war's end. In any case, the German defeat in 1945 made the entire matter moot.

\section{CONCLUSION}

Tellingly, Meyer-Abich and Jordan's alliance, forged from their shared experience as scientific and ideological outcasts in the Nazi state, did not long survive that state's demise. Jordan, jobless, slowly proceeding through formal denazification and attempting to find a new academic position in the Western occupation zones, resigned as coeditor of Physis in December 1945. MeyerAbich did manage to rescue the journal, but only barely: a second Physis issue, "Volume 2/3,"

\footnotetext{
${ }^{66}$ Marquardt to Meyer-Abich, 14 Nov. 1944, Nachlass Meyer-Abich, Bd 38. Mrugowsky was not listed as a contributor for this Wehrmacht version of the issue; perhaps Meyer-Abich intuited that associating his journal with such a high-ranking SS member would look unseemly after the war.

${ }^{67}$ Jordan to Meyer-Abich, 3 Oct. 1944, p. 1, Nachlass Meyer-Abich, Ba 1 (I thank Kevin Amidon for his help in locating this letter); and Marquardt to Meyer-Abich, 21 Nov. 1944, Nachlass Meyer-Abich, Bd 38 (urgency level).

${ }^{68}$ On the Wehrmachtausgaben see Bühler and Bühler, Der Frontbuchhandel 1939-1945 (cit. n. 61), pp. 184-218; and Barbian, Literaturpolitik im NS-Staat (cit. n. 61), pp. 190-191.

${ }^{69}$ Marquardt to Meyer-Abich, 14 Nov. 1944, Nachlass Meyer-Abich, Bd 38. On the corruption of the Wehrmacht book publishing industry see, e.g., Hans E. Bühler and Olaf Simons, Die blendenden Geschäfte des Matthias Lackas: Korruptionsermittlungen in der Verlagswelt des Dritten Reichs (Köln: Marteau, 2004).
} 
appeared in 1949, with Meyer-Abich now the sole editor and Jordan one of five "collaborators," yet the new volume received little attention and the journal died in obscurity. Meyer-Abich would continue to advocate for holism in the early Federal Republic, in vain, while Jordan's scientific interests gradually turned away from biophysics and toward cosmology and general relativity. ${ }^{70}$

The wartime Physis saga leads to two conclusions. First, through both Physis and the campaign of intrigue behind the scenes, Meyer-Abich and Jordan attempted to bend the Nazi state to their own designs in an effort to smash their opponents and institutionalize Jordan's bold vision of science on an industrial scale. Aiming to gain monetary and political support for their heterodox scientific program, they were willing, even eager, to infuse Jordan's blueprint for big science with overt paeans to Nazi political goals. ${ }^{71}$ And to benefit Nazi propaganda in the occupied countries, Meyer-Abich and Jordan were glad to portray their journal as an ideologically sound enterprise for the "new Europe." Reinforcing the notion that it would necessarily be "German-led," they were happy to include articles by German scholars who had accepted posts in the occupied countries; they also actively recruited contributions even from those most complicit in war crimes, like Mrugowsky. And yet despite this Herculean effort to cater to Nazi whims, Physis was essentially a failure. Despite repeated appeals to the Reich Student Leadership, the Foreign Office, and the Wehrmacht, a patron was never found. Even the plan to feature publications by Mrugowsky, a man very close to the regime's inner circle, had little impact. Nevertheless, deep into the war Meyer-Abich and Jordan were still quite eager to identify and portray their ideas as compatible - even the best possible fit-with Nazi ideology; they were eager to "work towards the Führer" in science. Jordan and Meyer-Abich can thus be classified as "failed collaborators" with the Nazi state.

The second conclusion perhaps contains a deeper warning. In 1941 and 1942, at the peak of Hitler's empire, Jordan almost perfectly envisioned the industrial-scale big scientific enterprise that emerged in the United States during and after World War II (and then spread across the globe). The resemblance is indeed remarkable; Jordan, amazingly, came to many of the same conclusions that the American science administrator Vannevar Bush would reach in his famous 1945 report to the president, Science, the Endless Frontier. Both emphasized how the cost and scale of science were now so great that financial support from the state was a necessity. ${ }^{72}$ Both were concerned about maintaining intellectual freedom for brilliant individuals in this large enterprise. $^{73}$ And via similar reasoning, both came to the verdict that-somewhat paradoxically"basic" science needed to be prioritized over "applied" research. ${ }^{74}$

These two visions of big science arose organically, and independently, in vastly different political contexts. One was born in the Nazi milieu, as Germany appeared unstoppable on the European continent, and was an attempt to make science "work towards the Führer." The other was

\footnotetext{
${ }^{70}$ For Jordan's resignation see Jordan to Meyer-Abich, 21 Dec. 1945, Nachlass Meyer-Abich, Ba 1. I thank Kevin Amidon for his help in locating this letter. For the new issue see Adolf Meyer-Abich, ed., Physis: Beiträge zur Natunwissenschaftlichen Synthese, 1949, 2/3. On postwar developments see Amidon, "Adolf Meyer-Abich, Holism, and the Negotiation of Theoretical Biology" (cit. n. 2), pp. 358-359.

${ }^{71}$ Admittedly, Meyer-Abich was less interested in big science in and of itself; he saw Jordan's vision as a politically expedient way to promote his scientific interests. For Jordan the converse was true: he was motivated by his vision of big science, while holism was less important. Again, it is no coincidence that this unlikely alliance dissolved quickly after the German defeat in 1945.

${ }^{72}$ Vannevar Bush, Science, the Endless Frontier (Washington, D.C.: Office of Scientific Research and Development, 1945), p. 7.

${ }^{73}$ Jordan's view is elaborated above; Bush noted that "scientific progress on a broad front results from the free play of free intellects, in the manner dictated by their curiosity for exploration of the unknown": ibid.

${ }^{74}$ Jordan asserted that "pure [i.e., basic] research must precede applied research," while Bush claimed that "basic research is the pacemaker of the technological process." See Jordan, "Naturwissenschaft im Umbruch" (cit. n. 27), p. 453; and Bush, Science, the Endless Frontier, p. 14.
} 
born in Allied victory, framed as a product of American ingenuity and freedom. ${ }^{75}$ Yet at their core, both laid out the same vision for big science - and so we must conclude that there is nothing inherently democratic about the concept. After all, Jordan's vision of centrally led institutes harmonized well with the Nazi ideology, and while he certainly "Nazified" his plan for big science via slogans and vocabulary, the basic top-down organizational system of big science is inherently semiauthoritarian. Moreover, Jordan's failure to implement his vision in the Nazi state was more contingent than it may seem. Had he been savvier and located the right power brokers in the Nazi polycracy, or had the regime been more amenable to ideas from sympathetic intellectuals - and had the course of the war taken a different turn - it is scarily conceivable that something resembling Jordan's vision could have been constructed under Nazi auspices in Europe. The Physis story thus provides another chilling reminder that there is nothing inherently irreconcilable between modern large-scale science and an antidemocratic political system. ${ }^{76}$

\footnotetext{
75 "Without scientific progress we could not have maintained our liberties against tyranny": Bush, Science, the Endless Frontier, p. 6 .

${ }^{76}$ On the standard view that democracy is beneficial to science, and authoritarianism damaging, see, e.g, Henry E. Sigerist, "Science and Democracy," Science and Society, 1938, 2:291-299; Robert K. Merton, "A Note on Science and Democracy," Journal of Legal and Political Sociology, 1942, 1:115-126; and Samuel A. Goudsmit, Alsos (1947; rpt., Woodbury, N.Y.: AIP Press, 1996), pp. xxxiii-xxxviii. On the revisionist view that democracy is not necessary to scientific success see, e.g., Yakov M. Rabkin and Elena Z. Mirskaya, "Science and Totalitarianism: Lessons for the Twenty-First Century," in Science and Ideology: A Comparative History, ed. Mark Walker (New York: Routledge, 2003), pp. 17-34.
} 